Seiji Ishikawa MD,

Koshi Makita MD,

Koichi Nakazawa MD,

Keisuke Amaha MD

\title{
Continuous intra-arterial blood gas monitoring during oesophagectomy
}

Purpose: To evaluate the clinical usefulness of the continuous intra-arterial blood gas (CIABG) monitoring system, Paratrend $7^{\mathrm{TM}}$, during differential lung ventilation (DLV) in 12 patients undergoing oesophagectomy.

Methods: Anaesthesia was induced with propofol and was maintained with isoflurane, oxygen and air, supplemented by an epidural infusion of mepivacaine. Arterial samples for estimation of blood gases (ABG) were taken just before and 5, 10,20,30,60, and 90 min after the pleura was opened. The $\mathrm{pH}, \mathrm{PO}_{2}$, and $\mathrm{PCO}_{2}$ values displayed by the CIABG monitor, which were recorded prior to the arterial blood sampling, were compared with the results of $A B G$ analysis.

Results: Eighty-four blood samples were obtained and the ranges for the measured variables were $\mathrm{PCO}_{2} 24.8$ $57.4 \mathrm{mmHg}, \mathrm{PO}_{2} 47-449 \mathrm{mmHg}$, and pH 7.30-7.49. The correlation between CIABG and ABG measurements was strong and significant ( $\mathrm{r}$ values : $\mathrm{PCO}_{2} 0.80, \mathrm{PO}_{2} 0.93, \mathrm{pH} 0.94$ ). The overall bias \pm precision between the two methods was $\mathrm{PCO}_{2} 0.9 \pm 3.1 \mathrm{mmHg}, \mathrm{PO}_{2}-1 \pm 40 \mathrm{mmHg}, \% \mathrm{PO}_{2} 0.8 \pm 21.6 \%, \mathrm{pH} 0.00 \pm 0.02$. For $\mathrm{PO}_{2}$ values $<150 \mathrm{mmHg}$, the biases \pm precision were $\mathrm{PO}_{2}-5 \pm 17 \mathrm{mmHg}, \% \mathrm{PO}_{2}-2.1 \pm 20.7 \%$.

Conclusion: The agreement between $\mathrm{CIABG}$ and $\mathrm{ABG}$ measurements was better for $\mathrm{PCO}_{2}$ and $\mathrm{pH}$ than for $\mathrm{PO}_{2}$. Although the CIABG system is clinically useful for monitoring trends in blood gas changes, the accuracy of the $\mathrm{PO}_{2}$ value may be unacceptable during DLV because the error is theoretically $<34 \mathrm{mmHg}$ with $95 \%$ reliability in the clinically important range of $\mathrm{PO}_{2},<150 \mathrm{mmHg}$.

Objectif : Évaluer l'utilité clinique du système de monitorage continu des gaz sanguins par voie intra-artérielle (CIABG), Paratrend $7 \circledast$, durant la ventilation à un poumon chez 12 patients subissant une oesophagectomie.

Méthodes : Après induction au propofol, l'anesthésie a été maintenue à l'isoflurane avec air et oxygène, complétée d'une infusion péridurale de mépivacainne. Des gaz artériels $(A B G)$ ont été prélevés immédiatement avant l'ouverture de la plèvre de même qu'à $5,10,20,30,60$ et 90 min après son ouverture. Les valeurs du pH, $P O$ et $\mathrm{PCO}_{2}$ indiquées par le système de monitorage (CIABG), et enregistrées avant l'échantillonnage artériel, ont été comparées avec celles des gaz artériels.

Résultats : Quatre-vingt-quatre échantillons sanguins ont été prélevés et l'éventail des variables mesurées a été: $\mathrm{PCO}_{2} 24,8-57,4 \mathrm{mmHg}, \mathrm{PO}_{2} 47-449 \mathrm{mmHg}$ et pH 7,30-7,49. La corrélation entre les mesures effectuées par CIABG et celles effectuées par $A B G$ a été très bonne et significative (valeurs de $\mathrm{r}: \mathrm{PCO}_{2} 0,8, \mathrm{PO} 20,93, \mathrm{pH} 0,94$ ). La tendance globale \pm la précision entre les deux méthodes a été: $\mathrm{PCO}_{2} 0,9 \pm 3,1 \mathrm{mmHg}, \mathrm{PO}_{2}-1 \pm 40 \mathrm{mmHg}$, $\% \mathrm{PO}_{2} 0,8 \pm 21,6 \%, \mathrm{pH} 0,00 \pm 0,02$. Pour des valeurs de $\mathrm{PO}_{2}<150 \mathrm{mmHg}$, la tendance \pm la précision ont été pour la $\mathrm{PO}_{2}$ de $-5 \pm 17 \mathrm{mmHg}$ et pour le $\% \mathrm{PO}_{2}$ de $-2,1 \pm 20,7 \%$.

Conclusion : La concordance entre les mesures par CIABG et celles par $\mathrm{ABG}$ était meilleure pour la $\mathrm{PCO}_{2}$ et le $\mathrm{pH}$ que pour la $\mathrm{PO}_{2}$. Même si le système $\mathrm{CIABG}$ est utile cliniquement pour la surveillance des tendances de variations des gaz sanguins, la précision des valeurs de $\mathrm{PO}_{2}$ peut être inacceptable durant la ventilation à un poumon parce que l'erreur est théoriquement de $<34 \mathrm{mmHg}$ avec $95 \%$ de fiabilité dans la gamme de $\mathrm{PO}_{2}$ cliniquement importante soit $<150 \mathrm{mmHg}$.

From the Department of Anesthesiology and Critical Care Medicine, Tokyo Medical and Dental University, School of Medicine, 1-5-45 Yushima, Bunkyo-ku, Tokyo 113 Japan.

Address correspondence to: Dr. S. Ishikawa, Phone: 81-3-5803-5325; Fax: 81-3-5803-0150; E-mail: ishikawa.mane@med.tmd.ac.jp Accepted for publication November 29, 1997. 
$\mathrm{T}$ HE Paratrend $7^{\mathrm{TM}}$ (Pfizer Biomedical Sensors, UK), the only continuous intra-arterial blood gas (CIABG) monitoring system commercially available, is a multiparameter intravascular sensor system for on-line continuous measurement of $\mathrm{pH}, \mathrm{PCO}_{2}, \mathrm{PO}_{2}$ and temperature. The objective of the present study was to evaluate the clinical usefulness of the CIABG system during oesophagectomy with differential lung ventilation (DLV).

\section{Materials and methods}

Of 13 patients scheduled to undergo oesophagectomy with right thoracotomy, 12 with ASA physical status 1 or 2 were included in this study. One patient with pneumonia who may have required two-lung ventilation was excluded. The study was approved by the University's Ethical Committee and informed consent was obtained from all patients.

Anaesthesia was induced with $2 \mathrm{mg} \cdot \mathrm{kg}^{-1}$ propofol iv and was maintained with isoflurane $0.5-1.5 \%$, oxygen and air $\left(\mathrm{FIO}_{2}=0.8\right)$, supplemented by a continuous epidural infusion of mepivacaine. Tracheal intubation was facilitated with $0.2 \mathrm{mg} \cdot \mathrm{kg}^{-1}$ vecuronium iv and a left-sided double-lumen endotracheal tube (Broncho-cath ${ }^{\circledR}$, Mallinckrodt Inc, Argyle, NY) was used for DLV.

The intravascular sensor was advanced through a 20 -gauge arterial catheter placed in the radial artery to a length of $15 \mathrm{~cm}$. The monitoring system was calibrated to the conventional blood gas analysis according to the manufacturer's recommendation. The data collected by the monitoring system were corrected to the corresponding values at $37^{\circ} \mathrm{C}$.

Just before the pleura was opened, one-lung ventilation was commenced. The dependent lung was ventilated with a tidal volume of $6-8 \mathrm{ml} \cdot \mathrm{kg}^{-1}$ and the respiratory rate was increased by $20-50 \%$ to keep $\mathrm{PaCO}_{2}$ at approximately $40 \mathrm{mmHg}$. If severe hypoxaemia $\left(\mathrm{SpO}_{2} \leq 90 \%\right)$ was recognised during one-lung ventilation, major causes of hypoxaemia (e.g., doublelumen tube malposition, poor haemodynamic status) were eliminated and, if required, differential lung CPAP/PEEP and/or intermittent non-dependent lung ventilation ${ }^{1}$ were performed. The monitoring system was recalibrated at the beginning of the intra-abdominal procedure (reconstruction using the stomach) in the supine position. The lungs were ventilated at a constant tidal volume (VT $=10 \mathrm{ml} \cdot \mathrm{kg}^{-1}$ ) using an $\mathrm{FIO}_{2}$ of 0.5 . The respiratory rate was adjusted to maintain normocapnia.

Arterial blood for conventional blood gas analyses $(A B G)$ was sampled and analysed without delay on a laboratory blood gas analyser (STAT Profile $5^{\mathrm{TM}}$ gas analyser, NOVA Biomedical, USA) just before the pleura was opened, and $5,10,20,30,60$, and $90 \mathrm{~min}$ after opening the chest and $30,60,90$, and $120 \mathrm{~min}$ after abdominal surgery was started. Just before arterial blood sampling, the CIABG data were recorded for the comparison with $A B G$ data using a correlation analysis and the method of Bland and Altman. ${ }^{2}$

\section{Results}

The ranges of the $\mathrm{ABG}$ variables were $\mathrm{PCO}_{2}: 24.8-57.4$ $\mathrm{mmHg}$ and $30.3-46.6 \mathrm{mmHg}, \mathrm{PO}_{2}: 47-449 \mathrm{mmHg}$ and $72-255 \mathrm{mmHg}$, and $\mathrm{pH}: 7.30-7.49$ and 7.34-7.47, respectively (thoracic and abdominal). In the early stage of DLV, the $\mathrm{PaO}_{2}$ decreased abruptly from $386 \pm 49$ $\mathrm{mmHg}$ to $172 \pm 84 \mathrm{mmHg}$ and remained at approximately $150-200 \mathrm{mmHg}$ thereafter.

The correlation between CIABG and ABG measurements was strong and significant for each parameter. The precision of the $\% \mathrm{PO}_{2}$ measurements was twice as great in the thoracic part of the operation as in the abdominal part (Table I).

The $\%$ bias and the \% precision of the $\mathrm{PO}_{2}$ measurements were markedly increased at five minutes after opening the chest, however these changes were temporary. The \% precision of the $\mathrm{PO}_{2}$ data collected during the latter part of the thoracic procedure was approximately twice as great as that of the data collected during the abdominal procedure (Table II). Two sensors showed signs of the formation of clots covering the sensor tip ${ }^{3}$ during intra-abdominal procedure but such signs were not found in any patient during the intra-thoracic procedure.

\section{Discussion}

We have assessed the agreement between CIABG and $A B G$ data by utilising the method of Bland and Altman. ${ }^{2}$ The bias and the precision values of $\mathrm{PCO}_{2}$ and $\mathrm{pH}$ during DLV in the present study were similar to those reported in other situations such as intensive care ${ }^{4}$ and open heart surgery. ${ }^{5}$ As the lungs of our patients were ventilated to maintain $\mathrm{PaCO}_{2}$ at approximately $40 \mathrm{mmHg}$, dynamic changes in the $\mathrm{PaCO}_{2}$ or $\mathrm{pH}$ were not observed during DLV. Adjusting the respiratory rate to keep the $\mathrm{PaCO}_{2}$ constant may have resulted in acceptable accuracy in the $\mathrm{PaCO}_{2}$ and $\mathrm{pH}$ measurements.

Although the bias of each parameter was within acceptable limits, ${ }^{6}$ the precision of the $\mathrm{PO}_{2}$ values during the intra-thoracic procedure was larger than the precision in published reports ${ }^{4,5}$ as well as being larger than that during the intra-abdominal procedure in our study. Even in the clinically important range of $\mathrm{PO}_{2},<150$ $\mathrm{mmHg}$, the error will be theoretically $<34 \mathrm{mmHg}$ with 
TABLE I Statistical comparison of the continuous intra-arterial blood gas monitoring values with simultaneous arterial blood gas analysis.

\begin{tabular}{|c|c|c|c|c|c|c|}
\hline & $\begin{array}{l}\mathrm{PCO}_{2} \\
\left(m m H_{g}\right)\end{array}$ & $\begin{array}{l}\mathrm{PO}_{2} \\
\left(m m \mathrm{Hg}_{\mathrm{g}}\right)\end{array}$ & $\begin{array}{l}p H \\
(p H \text { unit })\end{array}$ & $\begin{array}{l}\% \mathrm{PO}_{2} \\
(\%)\end{array}$ & $\begin{array}{l}\mathrm{PO}_{2}<150 \mathrm{mmHg} \\
(\mathrm{mmHg})\end{array}$ & $\underset{(\%)}{\% \mathrm{PO}_{2}}\left(\mathrm{PO}_{2}<150 \mathrm{mmHg}\right)$ \\
\hline \multicolumn{7}{|l|}{ Thoracic part } \\
\hline \multicolumn{7}{|l|}{ Linear regression } \\
\hline Slope & 0.71 & 0.96 & 1.07 & & & \\
\hline Intercept & 12.67 & 6.60 & -0.53 & & & \\
\hline Pearson's r value & 0.80 & 0.93 & 0.94 & & & \\
\hline$P$ & $<0.001$ & $<0.001$ & $<0.001$ & & & \\
\hline Bias & 0.9 & -1 & 0.00 & 0.8 & -5 & -2.1 \\
\hline Precision & 3.1 & 40 & 0.02 & 21.6 & 17 & 20.7 \\
\hline \multicolumn{7}{|l|}{ Abdominal part } \\
\hline \multicolumn{7}{|l|}{ Linear regression } \\
\hline Slope & 0.67 & 1.02 & 0.80 & & & \\
\hline Intercept & 12.29 & -4.13 & 1.50 & & & \\
\hline Pearson's $r$ value & 0.61 & 0.87 & 0.59 & & & \\
\hline$P$ & $<0.001$ & $<0.001$ & $<0.001$ & & & \\
\hline Bias & 0.6 & 0 & -0.01 & -0.2 & & \\
\hline Precision & 3.1 & 21 & 0.04 & 11.8 & & \\
\hline
\end{tabular}

TABLE II Sequential changes of the bias and the precision between the continuous intra-arterial blood gas monitoring and the arterial blood gas analysis.

\begin{tabular}{|c|c|c|c|c|c|c|c|c|c|c|c|c|}
\hline & & Base line & $T 5$ & $T 10$ & $T 20$ & $T 30$ & $T 60$ & 790 & $A 30$ & $A 60$ & $A 90$ & $A 120$ \\
\hline \multirow[t]{2}{*}{$\mathrm{PCO}_{2}$} & bias & 0.5 & 1.7 & 1.1 & 0.6 & 0.3 & 1.3 & 0.8 & 0.2 & 0.5 & 1.0 & 0.7 \\
\hline & precision & 2.3 & 4.9 & 2.3 & 4.0 & 2.8 & 2.4 & 3.0 & 2.8 & 3.1 & 3.4 & 3.4 \\
\hline \multirow[t]{2}{*}{$\% \mathrm{PO}_{2}$} & bias & 1.6 & 22.8 & 4.4 & -3.1 & -2.1 & -10.6 & -7.5 & -0.2 & 0.8 & -1.4 & 0.1 \\
\hline & precision & 8.9 & 27.2 & 12.3 & 12.1 & 24.7 & 21.2 & 23.6 & 9.3 & 14.3 & 11.9 & 12.5 \\
\hline \multirow[t]{2}{*}{$\mathrm{pH}$} & bias & 0.01 & 0.00 & 0.00 & 0.00 & 0.00 & 0.00 & 0.01 & 0.00 & -0.01 & -0.02 & -0.03 \\
\hline & precision & 0.02 & 0.01 & 0.02 & 0.02 & 0.01 & 0.02 & 0.02 & 0.01 & 0.02 & 0.04 & 0.05 \\
\hline
\end{tabular}

Base line, T5, T10, T20, T30, T60, T90; Just before and 5, 10, 20, 30, 60, 90 min after opening the pleura. $\mathrm{A} 30, \mathrm{~A} 60, \mathrm{~A} 90, \mathrm{~A} 120 ; 30,60,90,120 \mathrm{~min}$ after starting the abdominal part of the surgery.

95\% reliability, suggesting that the true $\mathrm{PO}_{2}$ may be in the range of plus or minus $34 \mathrm{mmHg}$ of the monitored $\mathrm{PO}_{2}\left(\mathrm{PO}_{2}(\mathrm{P} 7)\right)$. Although the strong correlation between $\mathrm{CIABG}$ and $\mathrm{ABG}$ for each parameter indicates that the CIABG system is clinically useful for monitoring trends in blood gas changes, the accuracy of the $\mathrm{PO}_{2}$ (P7) value may be unacceptable during DLV.

The precision of the $\mathrm{PO}_{2}$ measurements made during DLV may have been influenced by the response time of the sensor. Venkatesh $e t$ al. $^{4}$ measured the $90 \%$ response time for $\mathrm{PO}_{2}$ and estimated that it was $70 \mathrm{sec}$, suggesting that it takes more than one to two minutes for CIABG readings to equilibrate to the true $\mathrm{PaO}_{2}$ when $\mathrm{PaO}_{2}$ changes rapidly such as the change in the $\mathrm{FIO}_{2}$ and maybe during DLV. The large bias in the $\mathrm{PO}_{2}$ data in the initial stage of one-lung ventilation may also be a result of the slow response time of the sensor. The $\mathrm{PaO}_{2}$ is largely reduced after the induction of one-lung ventilation, so $\mathrm{PO}_{2}(\mathrm{P} 7)$ also decreases after the change in the true $\mathrm{PaO}_{2}$.

In conclusion, the agreement of data between CIABG and $\mathrm{ABG}$ was acceptable for $\mathrm{pH}$ and $\mathrm{PCO}_{2}$. The accuracy of the $\mathrm{PO}_{2}$ value of the CIABG system may be unacceptable due to the slow response time of the sensor when arterial blood gas values are rapidly fluctuating, although the strong correlation between CIABG and $A B G$ data suggests that the CIABG system is clinically useful for monitoring trends in blood gas changes. Occasional blood sampling may be required for checking CIABG monitoring during DLV.

\section{References}

1 Benumof $J L$. Conventional and differential lung management of one-lung ventilation. In: Benumof JL (Ed.). Anesthesia for Thoracic Surgery, 2nd ed. Philadelphia: W.B. Saunders Co., 1995: 406-31.

2 Bland JM, Altman DG. Statistical methods for assessing agreement between two methods of clinical measurement. Lancet 1986; i: 307-10.

3 Mabutte CK, Sassoon CSH, Muro JR. et al. Progress in the development of a fluorescent intravascular blood gas system in man. J Clin Monit 1990; 6: 147-57.

4 Venkatesh B, Clutton Brock TH, Hendry SP. A multiparameter sensor for continuous intra-arterial blood gas 
monitoring: a prospective evaluation. Crit Care Med 1994; 22 : 588-94.

5 Venkatesh B, Clutton-Brock TH, Hendry SP. Evaluation of the Paratrend 7 intravascular blood gas monitor during cardiac surgery: comparison with the $\mathrm{C4000}$ in-line blood gas monitor during cardiopulmonary bypass. J Cardiothorac Vasc Anesth 1995; 9: 412-9.

6 Shapiro BA, Mabutte CK, Cane RD, Gilmour IJ.

Clinical performance of a blood gas monitor: a prospective multicenter trial. Crit Care Med 1993; 2: 487-94. 